Proc. Indian Acad. Sci. (Earth Planet, Sci.), Vol。91, No. 1, March 1982, pp. 55-63. (c) Printed in India.

\title{
Mineralogy and chemistry of the iron ores of Nainarmalai, Tamilnadu
}

\author{
N SUBBA REDDY, $V$ PULLA REDDY, A ANNAMALAI* and \\ C V R K PRASAD \\ Department of Geology, S V University, Tirupati 517 502, India \\ *State Geology Department, Madras 600 032, India
}

MS received 21 May 1981; revised 3 October 1981

\begin{abstract}
The magnetite-quartzites of Nainarmalai forms part of a large iron ore belt of Tamilnadu which occurs in a high grade granulite terrain. They are associated with basic granulites and gneisses. Mineralogical and chemical studies indicate their similarities with other metasedimentary iron ores.
\end{abstract}

Keywords. Magnetite-quartzites; metasedimentary; magnetites; ferride elements; chemical studies.

\section{Introduction}

The low grade iron ore deposit occurring on the NE arm of the ' $V$ ' shaped Nainarmalai hill $\left(78^{\circ} 12^{\prime} 30^{\prime \prime}: 11^{\circ} 19^{\prime} 30^{\prime \prime}\right)$ in Salem district is a banded magnetite-quartzite. This deposit forms part of $200 \mathrm{~km}$ long NE-sw belt of iron ore deposits in Tamilnadu occurring in the Archaean high grade granulite terrain (Windley 1977). Rao et al (1976) carried out investigations on the ore potentialities. Aiyengar (1945) recorded two bands of magnetite-quartzites on Nainarmalai. In this paper a study of mineralogy and chemistry of the magnetite-quartzites is presented and the origin of iron formation is discussed.

\subsection{Geology of the area}

Magnetite-quartzites are generally found as long thin bands, two to three in number, which alternate with pyroxene granulites. The trends of these are parallel to the associated garnetiferous gneisses and quartzofelspathic gneisses. The rocks are folded repeatedly and are broken by NE-SW trending faults. Pyroxenites, dolerite dykes, pegmatites and quartz veins are found as intrusives. Generally the area is in a granulite facies metamorphism but retrogression has taken place as evidenced by the formation of amphiboles at the expense of pyroxene. Magnetite-quartzites are coarse grained, dense, and brownish black generally showing granular or banded structure and are mostly made up of quartz and magnetite. The thickness of the magnetite bands vary from $2 \mathrm{~mm}$ to $20 \mathrm{~mm}$. At places magnetite is concentrated into lenses. Magnetite-quartzites together with the associated rocks show inward dips and the ' $V$ ' shaped structure is a syncline. A location map showing the distribution of iron ores of Tamilnadu is given in figure 1 . 


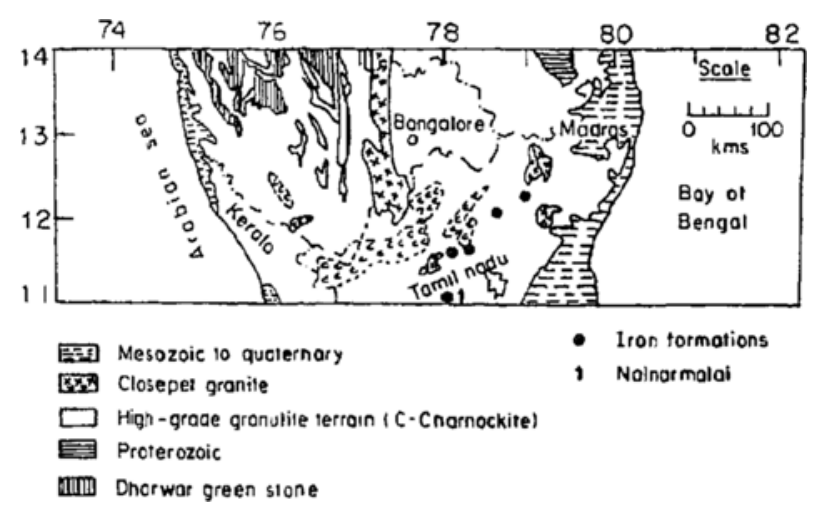

Figure 1. Geological map of a part of South India showing the location of iron formations in Tamilnadu.

\section{Methods of study}

Thirty one magnetite-quartzite samples were collected for mineralogical and textural studies, both under transmitted and reflected light. Whole rock chemical analysis for 5 samples of magnetite-quartzites was carried out colorimetrically for $\mathrm{SiO}_{2}, \mathrm{Al}_{2} \mathrm{O}_{3}$, $\mathrm{TiO}_{2}, \mathrm{Fe}_{2} \mathrm{O}_{3}, \mathrm{MgO}, \mathrm{CaO}, \mathrm{MnO}$ and $\mathrm{P}_{2} \mathrm{O}_{5}$. A unicam sP 500 Spectrophotometer was used. $\mathrm{FeO}$ was determined by permanganometric method. Fresh samples collected from exploratory pits were used in the analysis.

The distribution of trace elements in 8 samples of magnetites separated from magnetite-quartzites were studied for the elements $\mathrm{Co}, \mathrm{Cr}, \mathrm{Cu}, \mathrm{Mn}, \mathrm{Ni}, \mathrm{Ti}, \mathrm{V}$ and $\mathrm{Zn}$ by AAS (Perkin Elmer model 303 instrument). The magnetites were separated from magnetite-quartzites first by hand magnet after crushing. Further purification and separation was carried out by clerici solution, bromoform and acetone.

\section{Microscopic Studies}

Thin section study of magnetite-quartzites reveal the presence of magnetite and quartz predominantly with minor amounts of grunerite, hypersthene, hedenbergite, eulite, garnet, and apatite. Model analyses ranges and averages are given in table 1.

Iron oxide minerals occur mostly as elongated, rounded or irregular grains forming bands with a granoblastic texture. The association of iron oxide and quartz varies from purely granular (figure $2 a$ ) to well banded varieties with alternating layers of quartz and magnetite (figure 2b). Quartz shows distinct undulose extinction which suggests that the rocks have suffered considerable shearing stress. Development of numerous cracks in quartz grains are noticed which are filled with iron oxide. Hypersthene occurs usually in the form of small irregular grains and occasionally as bigger grains. Quartz and euhedral grains of magnetite are enclosed within hypersthene grains showing a type of sieve texture. Hypersthene occurs as inclusions within magnetite. It is moderate to strongly pleochroic, $x=$ pink, $y=$ yellow, and $z=$ pale green. The optic axial angle varies from $60^{\circ}$ to $65^{\circ}$. Birefringence $(\gamma-\alpha)$ ranges from 0.016 

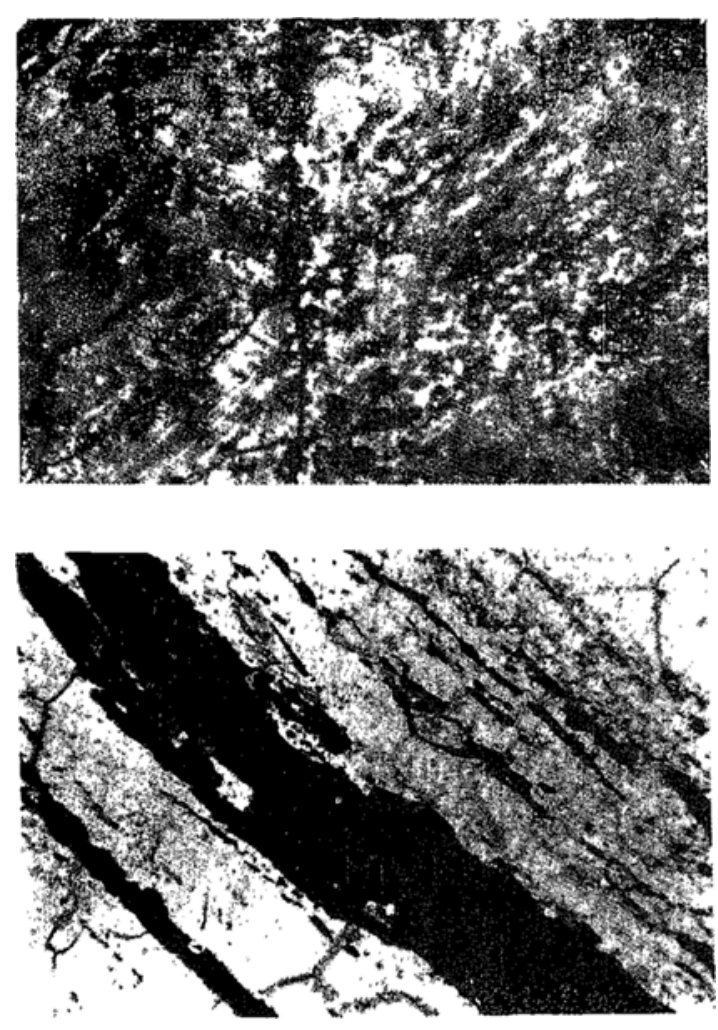

들

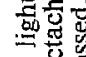

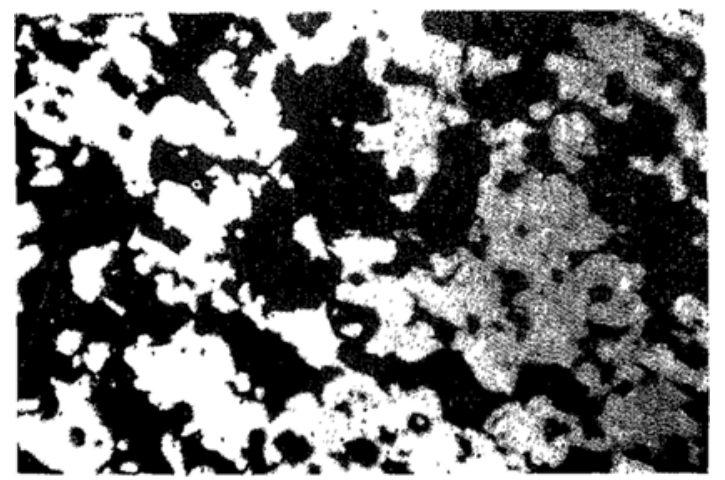

⿶凵

总苞

혐해

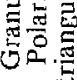

ส 선현

离离 
Table 1. Average and ranges of model analyses of magnetite-quartzites

\begin{tabular}{lcc}
\hline & Average & Range \\
\hline Iron Ore & $49 \cdot 77$ & $43 \cdot 50-56.76$ \\
Quartz & 41.46 & $38 \cdot 80-47.45$ \\
Hypersthene & $5 \cdot 33$ & $2 \cdot 70-9 \cdot 40$ \\
Hedenbergite & 1.43 & $1 \cdot 20-1 \cdot 60$ \\
Grunerite & $2 \cdot 90$ & $1.20-3.80$ \\
Garnet & 2.23 & $2 \cdot 20-2.50$ \\
Eulite & - & $0.00-1.75$ \\
Apatite & - & $0.00-0.05$ \\
\hline
\end{tabular}

to 0.018 . From these properties it is considered that the mineral is ferrohypersthene. It is found in different degrees of alteration giving rise to chlorite, actinolite, and hornblende. A dusty iron oxide released due to the alteration of hypersthene sometimes occupies cleavages and cracks giving a reticulate pattern. Grunerite is found as colourless grains. It has large $2 \mathrm{~V}(-)$ varying from $75^{\circ}$ to $80^{\circ}$ and $Z \Lambda C$ varies between $12^{\circ}$ to $15^{\circ}$. Birefringence $(\gamma-\alpha)$ ranges between 0.019 to 0.021 . Hedenbergite is distinguished from hypersthene by its weak pleochroism in shades of green $X=$ sea green, $Y=$ bluish green, and $Z=$ pale yellowish green. Optic axial angle varies from $52^{\circ}$ to $58^{\circ}$ with $Z \wedge C$ ranging between $40^{\circ}$ and $54^{\circ}$. Birefringence $(\gamma-a)$ varies from 0.025 to 0.027 . In some sections eulite is noticed in association with magnetite and quartz. It is strongly pleochroic in $X=$ claret red, $Y=$ yellow, and $Z=$ sea green. $2 V(-)$ ranges between $15^{\circ}$ to $18^{\circ}$ and $(\gamma-\alpha)$ ranges between 0.017 to 0.019 . Mauvish pink, deep red, or brown garnet is found occasionally in some sections with grains of varying size and shape. These grains are isotropic and exhibit high relief, and are characterised by number of cracks. Apatite is generally found only in a few sections as small crystals, these are found sometimes protruding from the iron oxide grains. Mostly they are arranged parallel to the bands.

\subsection{Ore-microscopic studies}

Under reflected light magnetite is grey in colour with a brownish tinge. The degree of martitization is generally low, although the surface samples show much alteration to hematite characterised by the replacement and reliet textures (figure $2 \mathrm{c}$ ). The alteration is most pronounced at the margins and along (111) planes in the magnetite grains. With progressive oxidation the elongated hematite lamellae broaden and only residual areas of magnetite remains. In the final stage of replacement no magnetite is left but its previous presence is indicated by a Widmanstetten like texture in hematite (Edwards 1954). Reflectance of magnetite in air in green light ranges from $20 \cdot 4-21 \cdot 2 \%$. It is positive to etch reaction with $50 \% \mathrm{HNO}_{3}, 50 \% \mathrm{HCl}$, aquaregia and $\mathrm{SnCl}_{2}-\mathrm{HCl}$ solution. Vicker's hardness of magnetite ranges from 600 to 620 at $50 \mathrm{gms}$ load and goes gradually down at higher loads and this is in accordance with the observations of Nakhla (1956). Goethite and limonite are found as alteration products. It must be pointed out here that magnetite-quartzites contain mainly magnetite without any ilmenite and the alterations noticed are only scanty. 


\section{Chemical studies}

Whole rock chemical analyses for five samples of magnetite-quartzites are given in table 2. Kimberley (1979) has given chemical analyses of three different environmental types, the mineralogy of which is different from those of Nainarmalai and therefore a comparison of their chemical compositions cannot be made. The magnetite-quartzites belong to oxide facies, and no other facies (sulphide, silicate, carbonate) are met with in the rocks studied. The averages of Algoma and Superior oxide facies of Gross and Mcleod (1980) together with those of precambrian of Lepp and Goldich (1964) and of Archaean iron formations of Gole and Klein (1981) are given in table 3. Although the number of analyses of the present study are few (table 2) a comparison of their averages with those of others in general shows that the Nainarmalai magnetite-quartzites are chemically different from other precambrian iron formations in spite of some similarities in a few constituents. However their chemical distinctness may not be significant if the wide ranges in compositions reported are taken into account.

The distribution of trace elements $\mathrm{Co}, \mathrm{Cr}, \mathrm{Cu}, \mathrm{Mn}, \mathrm{Ni}, \mathrm{Ti}, \mathrm{V}$, and $\mathrm{Zn}$ in the separated magnetites from magnetite-quartzites are shown in table 4 . In all the samples Co is below $10 \mathrm{ppm}$, whereas $\mathrm{Ni}$ varies from $20 \mathrm{ppm}$ to $40 \mathrm{ppm}$. Titanium in all the samples is below $250 \mathrm{ppm}$. Cr varies from $24 \mathrm{ppm}$ to $100 \mathrm{ppm}$ in different samples whereas $\mathrm{Mn}$ is present in higher proportions varying from $100 \mathrm{ppm}$ to $600 \mathrm{ppm}$. The proportions of $\mathrm{Cu}$ varies from $40 \mathrm{ppm}$ to $70 \mathrm{ppm}$.

\section{Discussion}

In the present study trace elements are determined for magnetites separated from the magnetite-quartzites. Hence a comparison of this data cannot be made with the determinations for whole rocks such as those of Gross and Mcleod (1980). However it is significant to note that Landergren (1948), Goldschmidt (1954) and Rankama and Sahama (1950) have suggested that in the sedimentary iron ores and in late magmatic differentiates, the ferride group of elements occur in low concentrations. Anjaneya

Table 2. Chemical analysis of magnetite-quartzites

\begin{tabular}{lrrrrr}
\hline & 1 & 2 & 3 & 4 & 5 \\
\hline $\mathrm{Total} \mathrm{Fe}$ & 38.14 & 37.78 & 32.08 & 37.21 & 42.70 \\
$\mathrm{Fe}_{2} \mathrm{O}_{2}$ & 39.65 & 37.82 & 33.28 & 38.83 & 36.76 \\
$\mathrm{FeO}$ & 13.42 & 14.60 & 11.28 & 12.95 & 21.88 \\
$\mathrm{Al}_{2} \mathrm{O}_{8}$ & 2.34 & 2.95 & 2.05 & 2.96 & 2.72 \\
$\mathrm{CaO}$ & 1.36 & 1.08 & 1.68 & 1.53 & 0.93 \\
$\mathrm{MgO}$ & 1.28 & 1.57 & 2.82 & 1.85 & 1.74 \\
$\mathrm{MnO}$ & 0.54 & 0.65 & 0.95 & 0.78 & 0.56 \\
$\mathrm{P}_{2} \mathrm{O}_{5}$ & 0.16 & 0.13 & -3.68 & 0.24 & 0.18 \\
$\mathrm{TiO}_{2}$ & 1.05 & 1.85 & 0.68 & 0.81 & 0.96 \\
$\mathrm{SiO}_{2}$ & 40.38 & 38.90 & 46.95 & 39.96 & 33.90 \\
& & & & & \\
\hline
\end{tabular}




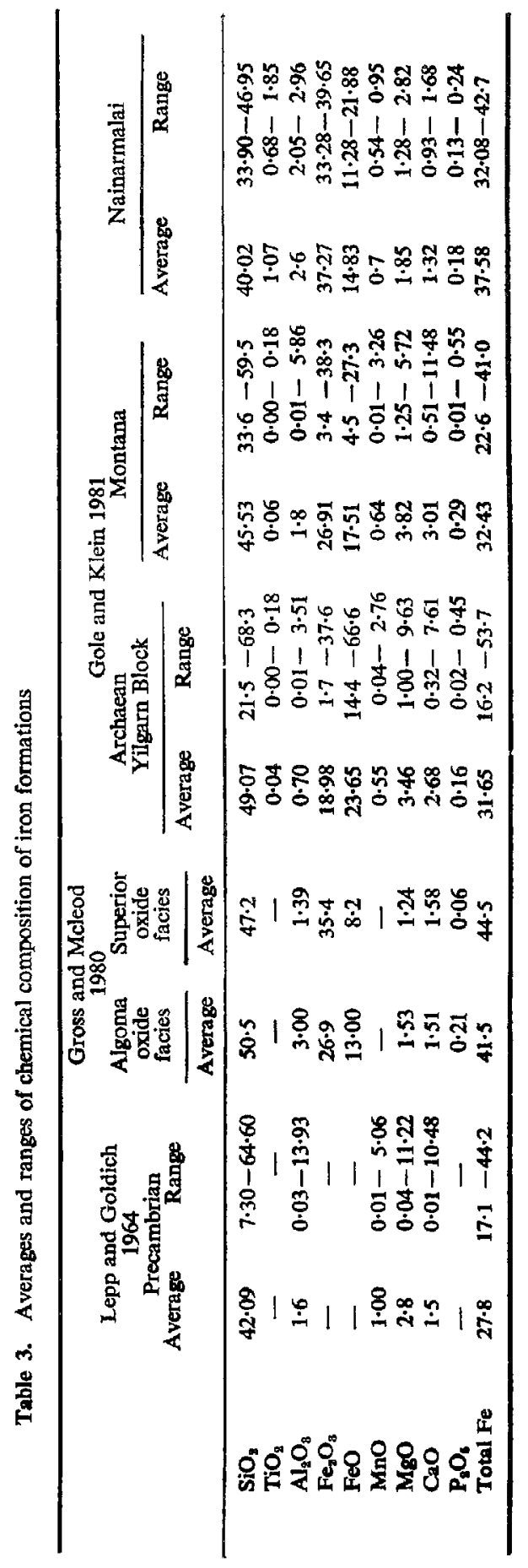


Table 4. Trace elements (in ppm) in magnetites

\begin{tabular}{ccccccccc}
\hline $\begin{array}{c}\text { Sample } \\
\text { No. }\end{array}$ & $\mathrm{Co}$ & $\mathrm{Ni}$ & $\mathrm{Cr}$ & $\mathrm{Ti}$ & $\mathrm{V}$ & $\mathrm{Mn}$ & $\mathrm{Zn}$ & $\mathrm{Cu}$ \\
\hline $\mathrm{N}_{2}$ & $\times$ & 40 & 75 & 125 & 25 & 600 & 50 & 45 \\
$\mathrm{~N}_{7}$ & $\times$ & 20 & 25 & 180 & $\mathrm{~N} . \mathrm{D}$. & $\mathrm{N} . \mathrm{D}$. & 55 & 80 \\
$\mathrm{~N}_{19}$ & $\times$ & 25 & 100 & 200 & $<20$ & 240 & 40 & 40 \\
$\mathrm{~N}_{14}$ & $\times$ & 25 & 25 & 125 & 30 & 180 & 50 & 60 \\
$\mathrm{~N}_{26}$ & $\times$ & - & 35 & 150 & - & 100 & 40 & 50 \\
$\mathrm{~N}_{18}$ & $\times$ & $\mathrm{N} . \mathrm{D}$. & 50 & 100 & $\mathrm{~N} . \mathrm{D}$. & $\mathbf{1 2 0}$ & 50 & 45 \\
$\mathrm{~N}_{23}$ & $\times$ & 40 & $<25$ & 250 & 25 & 160 & 35 & 55 \\
$\mathrm{~N}_{28}$ & $\times$ & 35 & 25 & 85 & 30 & 260 & 50 & 70 \\
\hline
\end{tabular}

N.D : Below detectable limits $(10 \mathrm{ppm})$

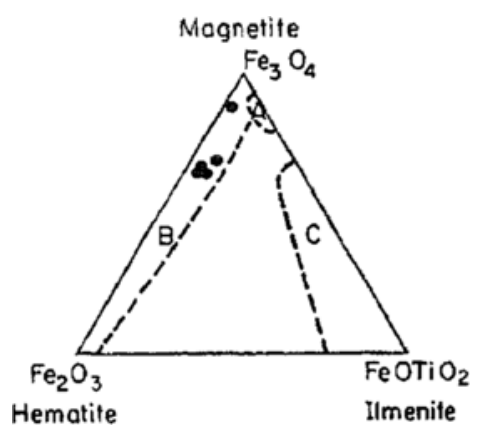

Figure 3. Composition diagrant of iron ores of Nainarmalai (after Balsely and Buddington 1958), A. Segregations with granite pegmatite, B. Hydrothermal replacement vein ore, $C$. Magmatic segregations.

Sastry and Krishna Rao (1970) from central Sweeden, Salem and Ongole (SouthIndia) and Rama Rao (1971) from Ongole have reported low concentration of $\mathrm{Co}, \mathrm{Ni}$, $\mathrm{V}, \mathrm{Cr}, \mathrm{Ti}$ and $\mathrm{Mn}$ from separated magnetites and the iron formations were considered by them as metasedimentary. The proportions of $\mathrm{Zn}$ varies from $35 \mathrm{ppm}$ to $55 \mathrm{ppm}$ in the samples studied but Sandell and Goldich (1943), Theobald and Thompson (1962), and Gramse (as referred by Wedepohl 1972) have shown that in general the concentration of $\mathrm{Zn}$ in magnetites of igneous rocks are higher than those of other origin. Similar low concentrations of the different trace elements as referred above are found in the samples studied. In contrast, the distribution of $\mathrm{Co}, \mathrm{Ni}, \mathrm{Ti}, \mathrm{Cr}, \mathrm{V}, \mathrm{Mn}$ and $\mathrm{Zn}$ elements in higher proportions are reported from magnetites of igneous origin by Howie (1955), Wager and Mitchell (1951), Gjelsvik (1957), Sen et al (1959), Kisvarsanyi and Proctor (1967), and Schock (1979). 'From the above discussion it may be suggested that the magnetite-quartzites are metasedimentary. This is supported by the simplicity in chemical composition of both silica and iron constituting about $90 \%$ and low concentrations of $\mathrm{TiO}_{2}, \mathrm{CaO}$, and $\mathrm{MgO}$ and presence of banding. The analyses when plotted on Balsley and Buddington (1958) composition diagram (figure 3), fall within the sedimentary field, indicating that these magnetite-quartzites 
are metasediments. Similar interpretations have been given for the magnetitequartzites of Satnur-Halgur areas of Southern Karnataka (Devaraju and Sadashivaiah 1966; Naganna and Mahabaleswar 1976). Further work is under progress for determining the relationship between magnetite-quartzites and the associated rocks, and to discuss their tectonic evolution.

\section{Ackno wledgements}

The authors thank Sri N G K Murthy, Sri P S Rao, Sri D R Davy and Sri K Raghunathan for the ir help in carrying out the field work

\section{References}

Aiyengar N K N 1945 Prog. Rep. GSI unpublished

Alexandro V R 1973 Econ. Geol. 681035

Anjaneya Sastry C and Krishna Rao I S R (1970) J. Geol. Soc. India 11242

Balsley J R and Buddington A 1958 Econ. Geol. 53777

Devaraju T C and Sadashivaiah M S $1966 \mathrm{~J}$. Geol. Soc. India 770

Edwards A B 1954 Textures of Ore minerals and their significance Aust. Inst. Min. \& Metal. (Inc.) Melbourne.

Gjelsvik T 1957 Econ. Geol. 52482

Goldschmidt V M 1954 Geochemistry (ed) A. Muir Oxford University Press.

Gole M J and Klein C 1981 J. Geol. 89169

Gross G A and Mcleod C R 1980 Can. Mineral 18223

Howie R A 1955 Trans. R. Soc. Edin 62725

Kimberley M M 1979 Chem. Geol. 25185

Kisvarsanyi G and Proctor P D 1967 Econ. Geol. 62449

Landergren S 1948 Sver. Geol, Inder Sok. Ser., C No. 496

Lepp $H$ and Goldich S S 1964 Econ. Geol. 591025

Naganna C and Mahabaleswar B 1976 In Proc. Symp. Geol. etc., of ferrous and ferro-ally minerals 7

Nakhla F M 1956 Econ. Geol. 51811

Rama Rao G V S 1971 Magnetic and mineralogical studies on the iron ores and the associated rocks of Eastern Ghats, Andhra Pradesh, India Unpubl. Ph.D. thesis, S V University

Rankama K and Sahama G 1950 Geochemistry. The University of Chicago Press

Rao P S, Raghunathan K and Davay D R 1976 In. Proc. Symp. Gol. etc. ferrous and ferro-alloy minerals 101

Sandell E B and Goldich S S 1943 J. Geol. Part I \& II 5199167

Schock H H 1979 Chem. Geol. 26119

Sen S, Nockolds S R and Allen R 1959 Geochim Cosmochim. Acta. 1658

Theobald P K and Thompson C E 1962 USGS Prof. Pap. 450 C-72

Wager L R and Mitchell R C 1951 Geochim. Cosmochim. Acta 129

Wedepohl K H (ea.) 1972 Hand book of geochemistry (New York: Springer-Veriag)

Windley B F 1977 Evolving continents (London : John-Wiley) 